\title{
The Intercultural Dynamics in Which the Discourses Take Place
}

Most of the time, first impressions are important. Before starting the research we visited the three cities to explore the field and connect with partners, stakeholders, and possible participants. Some of us had visited Abidjan and Yaoundé before, but Kinshasa was new to us all and certainly made an impression on us when we first visited in January 2015. The long highway from the airport to the city centre captures something of life in this lively capital. The road is full of all kinds of ancient cars and old buses shaking under heavy loads of people, as well as some very expensive suvs with tinted windows. On both sides of the highway people constantly stream by on foot and bicycles, carrying bags, goods - sometimes things that you really did not expect people to carry. Occasionally, a destination is revealed: one of us notices a coffin packed with all sorts of other things in a crowded car. Crossing the road is a real challenge for both pedestrians and drivers but happens quite regularly even on busy roads. Leaving the highway, our car slows down. The people are closer and appear to be walking fast. Most of them are young and very self-conscious about their outfits, often dressed to impress. They radiate energy and vitality. The older people move more slowly, shopping and chatting.

Everywhere impressive advertisements announce all kinds of events and a substantial number of the billboards we come across announce prayer meetings, retreats, or evangelistic rallies that promise 'blessing' or 'healing' and are led by 'prophets' or 'apostles'. Our first impression of Kinshasa was of a very crowded, energetic, and largely Christian city.

This brief impression of Kinshasa, recorded from the perspective of the researchers, introduces the more specific context of the research and should help the reader to understand the research population we offer in this chapter. The discourses we reconstruct and study in this book are part of larger educational dynamics in these contexts that are profoundly marked by intercultural exchange. In this chapter, we concentrate on some prominent characteristics of these dynamics, including their historical development and geographical variation. First, we introduce the argument of this chapter with three preliminary remarks. We then provide a short orientation on the countries in which the research took place, including an introduction to the cities, to enable the reader to 'land' in the concrete situation. Subsequently, we give an overview of 
the educational dynamics in the traditional, colonial, and independent periods, tracing the development of formal education which is one of the most important intercultural networks put into place in this region. In the colonial and independent/postcolonial periods we focus on the development of the African understanding of the French notion of laïcité, the separation of church and state. Finally, we describe the universities, which are prominent postcolonial institutions in this region and provide the settings for this inquiry.

\section{$1 \quad$ Preliminary Remarks}

We begin with three preliminary remarks in order to clarify the major concerns of this chapter. In the first place, some brief comments about our focus on the intercultural dynamics in which the discourses take place. The educational setting of the discourses is closely connected to a history of encounters between an impressive diversity of local peoples from francophone Africa and various representatives from the North Atlantic world. Decisive cultural interchanges with implications for education took place even before colonial times, as we will argue below. We therefore understand the contexts not as static backdrops, but as dynamics that give rise to, and find their continuation in, the discourses.

The dynamic approach to the context that we advocate for here is closely related to the use of GM в as a major research tool, which we introduced in the previous chapter. If we see each of the discourses as a system, we understand it as being fed by various incoming flows and existing as part of a bigger 'system. The entirety of the incoming flows is in fact an ungraspable quantity. Therefore, we do not pretend to give a complete description of the 'inflows' into the system in this chapter, but rather want to point to some crucial currents that contribute to and are continued in various ways in each of the discourses.

This emphasis on the ongoing processes of intercultural encounter and exchange not only helps to avoid a too rigid understanding of the different historical periods we mention, such as colonial and postcolonial, but also makes the relation between cultural characteristics and geography more flexible. Hence, one of the ideas behind an intercultural approach is the overcoming of cultural stereotypes (Boele van Hensbroek 2013, 34-38). An interesting detail in this respect is that in one of the pre-colonial encounters we just mentioned the representative of the North Atlantic world was a freed slave of African American origin as we will explain below. Nevertheless, this flexibility must not erase the importance of the (geographical and cultural) place where the 
discourses take place; the so-called 'positionality' (Hof 2016, 83). This underlines the concreteness or 'materiality' that makes both the encounters and the discourses possible (Mbembe 2001, cited in Hof 2016, 83n14).

In the second place, focusing more on positionality, we limit ourselves nearly exclusively to the interaction between traditional African and the North Atlantic cultures. This is justified by the fact that most formal educational programs and, more specifically, science as an academic enterprise, entered this region through interactions with Europe and North America. Consequently, however, other (mostly older) intercultural educational dynamics within subSaharan African cultures as well as in relation to Northern and Eastern Africa and Arabia through trade and religion (Islam) remain outside our perspective. We do not deny the importance of these influences for the educational practices in this region, but, from our perspective, they are less significant for the discourses on science among Christians as we have found no clear reference to them. Furthermore, in this context it is also important to acknowledge that Christianity from the North Atlantic world is also the product of an intercultural interplay. Therefore, the interaction with North Atlantic Christianity also enabled a mediated interaction with older cultural traditions, especially through the Bible, that were themselves not of North Atlantic origin. These Scriptures were translated into African languages from an early stage. Although we do not deny the influence of North Atlantic culture in the whole process of translation and transmission, it did nevertheless allow for a much more direct interaction with these traditions, which were also originally imported to Europe. African readers soon discovered that the world captured in these texts was much closer to their African traditional heritage in a number of respects than to the cultural context of the European and North-American missionaries who mediated these Scriptures to them. This was certainly evident in the close interest in ritual purity, sacrifice, and the rural context, as well as the interest in family ties and genealogies (cf. Bediako 1992, 1998). Although we acknowledge that 'traditional' is a contested term, we use it here as a reference to the ethnic cultural heritage that has contributed to the formation of peoples, and that is subject to change itself.

Finally, we limit the presentations of the countries and the cities due to space constraints. Rather than introduce the reader more profoundly to the complex social and political processes in which the three countries are caught up, we give short descriptions of some relevant elements from the different situations and only a small portion of their recent histories. Although we would like to offer more, and we are also convinced that this would be enriching, we want to avoid the temptation of attempting a comprehensive and allembracing understanding of what is happening because that is not the aim of 
this book. Instead we concentrate on the discourses produced by the participants. In this chapter we indicate the main possibilities and challenges of intercultural exchange in the contexts of the discourses. However, the limited information we offer clearly indicates that the connections with the North Atlantic world have a decisive impact on the social and political situations of the countries involved. The French language and France's colonial and postcolonial policies play a particularly prominent role, and the subsequent chapters will reveal how the discourses reflect this context.

As we explained in the preceding chapters, we have deliberately chosen three university cities from francophone countries in Africa with considerable differences in their relations to France and the North Atlantic world in general. In this section, we present some features of these countries and the intercultural exchange that takes place in these contexts. In the following descriptions we make use of information from the World Bank, an institution that is itself an instrument of intercultural politics in which the dominance of the North Atlantic world cannot be denied. Its so-called Social Adjustment Programs have especially influenced the economic, political, and social situations in the three countries mentioned below.

Education is convincingly shown to be one of the areas most affected by these programs (Reimers 1994). ${ }^{1}$ Our handling of the information from the World Bank is done with a certain restraint, in order to avoid the dominance of an economic instead of an intercultural focus.

\subsection{Ivory Coast and Abidjan}

The website of the World Bank provides a favourable image of Ivory Coast's financial and social situation. While there was a strong increase in poverty after 1985 until 2011, recent statistics show a remarkable economic recovery. This reversal, following the latest political crisis in 2010, is outstanding. The average real growth of the country's G DP between 2012 and 2015 is 8.5\% annually, making it "one of the highest rates in Sub-Saharan Africa" (World Bank 2016). This growth is driven by agriculture (mainly cacao, coffee, cotton, palm oil, and fruits), oil, industry, and services. The progress is beginning to influence the

1 The position of women is also severely affected. See for example Dzodzi Tsikata's article, https://www.globalpolicy.org/component/content/article/218/46625.html, accessed 15 October, 2018. 
poverty incidence; the estimated percentage of the population living below the poverty line in 2015 is $46 \%$ (World Bank 2016). ${ }^{2}$ During our periodical visits to Abidjan, we witnessed the rising investments in infrastructure related to this growth. Politically, a certain equilibrium seems to have been reached; the relatively quiet elections of 2015 that resulted in the re-election of president Ouattara could be interpreted as an indication that the political instability of the last decades has been overcome, at least for the time being. While the 2016 national referendum on the controversial new constitution was boycotted by the opposition, it did not lead to severe violent confrontations.

However, both positive developments also indicate that the improvements in Ivory Coast's situation have been achieved following a long period of crises and instability. Ivory Coast was once a wealthy country in West-Africa, especially during the first 25 years of autocratic rule by the legendary president Félix Houphouët-Boigny. He was the first leader of the independent state and maintained the presidency from independence in 1960 until his death in 1993. Houphouët invented the term 'Françafrique', which expresses his ideal for his country based on a close relationship with France, the former coloniser. However, his politics finally led to instability during the last period of his rule when he was forced to open up to a more democratic form of government. After his death, the conflicts increased. The political confrontations and civil wars (2002-2003 and 2010-2011) significantly impoverished the once envied country. The nature of Houphouët's administration and influence is crucial for understanding these severe crises (Hofnung 2011). Economic and ethnic diversity were made invisible within the overarching national identity ('Ivoirité'), which facilitated the national government's unequal treatment of the North and the South, leading to conflicts and consequently to the war (Bellamy and Williams 2011).

Although the World Bank's numbers highlight the success of president Ouattara's administration, the Human Rights Watch's agenda for Ivory Coast, 'To Consolidate this Peace of Ours' (2015), points to its weaknesses as well. The impunity for past human rights abuses and the continued abuse of power by security forces and police, but also the lack of a process of reconciliation on a local and regional level, the ongoing corruption, and the failure of land reforms show the problematic social and juridical side of the economic success. It is noteworthy that the religious differences that mark Ivory Coast receive so little attention in these presentations. According to one of the informants we interviewed in the first phase of our research, religion is not the dividing element in

2 See http://www.worldbank.org/en/country/cotedivoire/overview\#1, accessed on 15 October 2018. 
Ivorian society. According to him, ethnicity is far more divisive, a perspective that is confirmed by the literature (Page, Evans and Mercer 2010, 346). Muslims and Christians are both strongly present in Ivory Coast, the first stronger in the north of the country, the second predominantly in the south. Under Houphouët and his immediate successor the north was discriminated against (Bellamy and Williams 2011). The Global Religious Futures website indicates that $44 \%$ is Christian and $38 \%$ Muslim, although other sources indicate that the percentage of Muslims surpasses that of Christians. ${ }^{3}$ Apart from these two groups, a substantial part of the population is thought to adhere to an indigenous religion. The difficulty of mapping religion in this region of the world (and not only here) is, amongst other reasons, due to the multiple religious belonging of many people.

At first sight, the relationship with France has changed completely over the years; the situation is not the same as in the old days of 'le Vieux', as Houphouët was called. Ouattara is a former employee of the IMF, and the impact of this and other international institutions like the World Bank and the United Nations must not be underestimated. Regional cooperation within the Union Économique et Monétaire Ouest Africaine (UEMOA; eight French-speaking countries in West Africa that share the West African franc as a common currency) and cooperation with other bodies of continental cooperation like Ecowas and the African Union, encourage cultural exchange. However, this diversification cannot hide the fact that France is still prominently present in Ivory Coast. This presence was intensified during the period of crises and wars indicated above. France played the leading role in the international peacekeeping mission sent by the United Nations in 2011, bringing the French army back into the country. During the time of our research the French military was still active there. In a way, this implied a return to colonial rule because France's peacekeeping operations in Ivory Coast were built on the old colonial relation between the countries (Charbonneau 2014, 623-630). However, the most powerful and enduring instrument of France's influence is the use of French as the official language of the country (Kouadio N'Guessan 2008). Its contribution to the country's unity (there are approximately seventy languages spoken in Ivory Coast) makes it a constitutive part of the national identity. ${ }^{4}$ The ethnic and cultural diversity makes many administrative and political processes in the country deeply intercultural. The unstable periods of the last decades also affected Ivory Coast's international and intercultural relations with its neighbouring

3 See http://www.geocurrents.info/cultural-geography/religious-complexity-in-ivory-coast, accessed on 15 October 2018.

4 See http://www.axl.cefan.ulaval.ca/afrique/cotiv.htm, accessed on 15 October 2018. 
countries. Because of its wealth and stability, Ivory Coast once attracted a lot of migrants from the region. Even before its independence migrants, especially from Burkina Faso, came to work on its plantations. When instability and war affected Ivory Coast these migrants became a vulnerable group, especially in light of the nationalist rhetoric of 'Ivoirité' (Bjarnesen 2013, 17). This makes the regional interchanges far more complicated at the moment. ${ }^{5}$

In this research we worked with students and academics mainly from the city of Abidjan which is the economic and administrative centre of Ivory Coast. Although Houphouët made his home town Yamoussoukro the capital of the country in 1983, Abidjan remained the most important city and part of the national government is still situated here. The city is located in the Region des Lagunes, the most populated part of the country. Abidjan is situated near to the coast and developed fast during the last period of colonial rule. In $195^{\circ}$ a canal gave Abidjan direct access to the Atlantic Ocean and a big seaport was built. Abidjan is seen as the most important financial centre of Frenchspeaking West Africa. ${ }^{6}$ 'Le Plateau' is the prestigious financial district of the city, while the Cocody area is known for the campuses of various universities, of which the state's Université Félix Houphouët-Boigny is the most famous. This university's website communicates that it hosts 60,000 students. ${ }^{7}$ In 2014, Abidjan had nearly 5 million inhabitants, which is more than $20 \%$ of the total population of the country (23.4 million in 2016). In Abidjan, the cultural and ethnic diversity of the country, including its important migrant communities, is welcoming to people from overseas who are attracted by the financial facilities of the city, as well as its positive business climate and the country's natural resources and products. Although France keeps a firm grip on the construction of infrastructure, it is clear that other investors, mainly Chinese, are keen to participate in Ivory Coast's economy (Charbonneau 2014, 624-625). Together this creates a vibrant international context in which intercultural exchange is an intense everyday practice for most people.

\subsection{Cameroon and Yaoundé}

We now turn to Cameroon, part of the central African region. Its capital, Yaoundé, is the second location of our research. The governance of the first

5 An interesting detail is that president Ouattara is a descendant of migrants and that the accepted proposal of the new constitution also enlarges the possibility for migrants to become elected to democratic bodies and as president of the republic.

6 See https://www.britannica.com/place/Abidjan, accessed on 15 October 2018.

7 See http://univ-fhb.edu.ci/fr/index.php/ufhb/quelques-chiffres-de-l-ufhb, accessed on 15 October 2018. Only $10 \%$ of the students appear to be girls. It is not clear if these are the numbers of 2016 or a previous year. 
president of Cameroon, Ahidjo (1961-1982), and of his successor, Paul Biya (1982-present), are characterized by an autocratic style. That the latter had to accept a multiparty democracy in the 1990s did not really change this reality (Seemndze 2016, 163). Their long rules, despite some minor opposition that caused bloodshed (Nkwi 2013), brought a certain stability. Ahidjo was Muslim and Biya is Christian, although it is argued that it is not their religious affiliation but mainly their ethnic belonging and cultural politics that shape their political profiles (Konings and Nyamnjoh 2003, 6-7). According to the 'Global Religious Futures' website, $18 \%$ of Cameroon's population is Muslim and $70 \%$ Christian. ${ }^{8}$ However, despite the enduring relative stability, the economic results of the country are somewhat disappointing. In the 1980s Cameroon's economy was booming, but towards the end of the century it experienced various critical moments. Although the statistics from the last few years show a continuing and stable growth in the GDP, the number of poor people increased by $12 \%$ between 2007 and 2014, and the poverty is mainly concentrated in the northern region. Corruption and a lack of political transparency are indicated as important barriers to attracting more foreign investors who will stimulate (a more equal) economic growth. ${ }^{9}$

In population (23.3 million in 2015) Cameroon is equal to Ivory Coast, but its linguistic diversity is considerably richer. The country harbours 275 living indigenous languages. ${ }^{10}$ Because the colonial rulers drew the borders of countries without taking into account the communication lines and linguistic groups, a lot of Cameroon's ethnic groups have people of their group living in neighbouring countries (Eposi Ngeve \& Egbe Orock 2012). This means that international contacts do not automatically lead to intercultural exchange. Because of its complex colonial history, being first a German colony and then, after the First World War, a protectorate of the League of Nations governed partly by the British and partly by the French, both English and French are used for national communication. Although the French-speaking part is significantly larger, the country is officially bilingual (Seemndze 2016, 160-161). The multi-ethnic and multilinguistic composition of the country has greatly influenced the politics of the independent state and its struggle for national

8 See http://www.globalreligiousfutures.org/countries/cameroon/religious_demography \#/?affiliations_religion_id=o\&affiliations_year=2010, accessed on 16 October, 2018.

9 See http://www.worldbank.org/en/country/cameroon/overview, accessed on 16 October 2018.

10 See https://www.ethnologue.com/country/CM, accessed on 16 October 2018. However, one should take into account that defining the different languages and cultures in an African country is a contested activity, and therefore the considerable difference between Ivory Coast and Cameroon mentioned here should not be understood as a 'hard fact'. 
unity and identity. There is a shared perspective among social scientists that the two regimes that ruled the country after independence continued the colonial politics of manipulating cultural diversity for their own benefit. They therefore failed in their role as unifying agents of national identity (Page, Evans and Mercer 2010; Eposi Ngeve and Egbe Orock 2012; Seemndze 2016).

Although this kind of cultural politics also exists in the other two countries, it particularly affects the discourses from Yaoundé where a substantial group of Bamileke people participated in the research (see Chapter 4). The Bamileke, who originate from Western Cameroon, have an important role in the ethnic struggle for power and the cultural politics of both presidents in the postindependence period. The Bamileke were favoured during the rule of president Ahidjo, and many came to Yaoundé. This created tension with the Beti, the dominant group in Central Cameroon at that time. However, the current president, Paul Biya, is a Beti, and this affected the state's policy to the disadvantage of the Bamileke. According to Konings, the ethnic rivalry particularly affected the students' movement and the conflict at the University of Yaoundé in the nineties (Konings 2011, 27-30, 42 and 206).

Apart from the Anglophone region in the west, the predominantly Muslim northern part of the country appears to be especially vulnerable to this kind of political approach and subsequent conflicts (Seemndze 2016). The recent attacks by Boko Haram ${ }^{11}$ from neighbouring Nigeria and the invasion of refugees have destabilized the north even more. The Boko Haram network goes beyond Nigeria and links Cameroon with a powerful force in the region that is related to offshoots in other parts of the continent. This affects the whole country and provokes migration from the region of conflict towards the centre (Nkwi 2013). Another migrant stream comes from the Central African Republic. Refugees have entered Cameroon because of the violent clashes between invading Muslim militia, the national army, and local militias. Like Ivory Coast, Cameroon is involved in many forms of cooperation with its neighbouring countries as well as other partners from the continent. A similar economic and monetary union to the one in West Africa also exists in French-speaking Central Africa. The Central African franc (XAF) is the currency of Cameroon and five other Central African countries.

The relationships with the former colonizing countries are fundamental for Cameroon and its leadership. Because France maintains particularly close

11 Specialists confirm that the name 'Boko Haram' in Hausa, one of the languages in Northern Nigeria, means 'Western education is a sin ', see http://www.bbc.com/news/blogsmagazine-monitor-27390954, accessed 15 October 2018. This is definitely an evocative name in the context of this book. 
relations with its former colonies and does not like 'outside interference in their affairs' in general, it is also very much engaged with Cameroon. Some even claim that "cooperation policy is its main instrument of French power politics" and perceive France's aid acts "as the central cog in its patron - client machine at the heart of its relations with Africa" (Emmanuel 2010, 866-867). Emmanuel argues that the aid money from Paris maintained Biya in power during the call for democratization in the early 1990 (2010, 868). When German and American aid was declined in order to force Biya into opening up to democracy, France decided to augment their aid contribution to the country. They wanted the president as their loyal partner to continue in office, and Cameroon became, after Ivory Coast, the second most important destination of France's aid worldwide (Emmanuel 2010, 869-872). This example shows the political and economic impact of France in Cameroon, as well as the (military) importance of Cameroon for France's geopolitics. ${ }^{12}$ Cameroon is also a member of the British Commonwealth. In contrast to the French, the British have a more integrated policy of culture, development, and politics in their involvement with Cameroon (Torrent 2011). This implies that the British association with Cameroon is not likely to be dominated by geostrategic aims. Additionally, Nigeria is a far more important partner for British interests in this world region. Finally, Germany, as Cameroon's first European colonizing power has a particular influence on the country as well. We already mentioned Germany's involvement in the battle for democracy during the early 1990s. This 'critical loyalty' is still an important characteristic of Germany's contribution to Cameroon. ${ }^{13}$ As is the case for many African countries, China has recently become more and more important when it comes to international relationships, and Chinese engagement in education in Cameroon is remarkable (Nortveit 2011).

The city of Douala is Cameroon's major port and largest city. The capital Yaoundé is smaller, with approximately 2.5 million inhabitants, and is situated in the mountains towards the middle of the country. ${ }^{14}$ Yaoundé is a centre of administration and education and less an international centre of trade, as Douala is. However, as the capital and seat of the government it attracts people from all over the country and from abroad, and thus the city is developing fast. The government buildings give Yaoundé some of the grandeur of a capital,

12 See also the definition of the relationship between the countries at the website of the French government, http://www.diplomatie.gouv.fr/fr/dossiers-pays/cameroun/la-france -et-le-cameroun/, accessed on 16 October 2018.

13 See the website of the 'Deutsche Botschaft Jaunde', https://jaunde.diplo.de/, accessed on 16 October 2018.

14 See http://worldpopulationreview.com/countries/cameroon-population/, accessed on 16 October 2018. 
although in general it looks like a continuous clustering of neighbourhoods situated on nearly endless hillsides. The population of the city is very young, as it usually is in African cities, and education forms an important part of daily dynamics. The city harbours prestigious universities, such as the state universities Yaoundé I and Yaoundé II.$^{15}$ The website of Yaoundé I (the larger of the two universities) indicates that it hosts more than 55,000 students. The university is comprised of various faculties and what are called 'grandes écoles', and also four schools for doctoral programs.

\subsection{The Democratic Republic of Congo and Kinshasa}

Finally, we turn to Congo. Surprisingly, the World Bank's statistics for DRC show relatively positive results. The inflation rate of $53 \%$ in 2009 calmed down to $1 \%$ from 2013-2015. The high GDP growth over the last few years, nearly $8 \%$ for the period 2010-2015, was due to the high prices of natural resources on the world market. These prices fell in 2016 and therefore a much smaller growth is foreseen. Lamentably, few people have been taking advantage of the economic growth; DRC is among the poorest countries in the world and placed 176 out of 188 on the Human Development Index. ${ }^{16}$ In one of the meetings during our first orientation in Kinshasa in 2015 someone told us how steeply the production of agricultural products had fallen, and even basic food supplies came from abroad. This corresponds to the numbers of children with severe malnutrition, especially in the rural areas of the country ( $47 \%$ of the children), a result of wars and the neglect of the agricultural sector (Kismul, Hatløy, Andersen, Mapatano, Van den Broeck \& Moland 2015). A lot of people are displaced or have taken refuge outside the country. Contrary to Ivory Coast and Cameroon, DRC does not participate in economic or monetary unions. It is, however, deeply involved in all kinds of international relations, mostly related to the conflicts that plague the country and the trade of metals and minerals.

Recent quarrels between the government and opposition about the date of the elections in 2016 created instability again. ${ }^{17}$ This affected our research as it meant that we could not travel to Kinshasa in the autumn of 2016 for the last phase of the focus group sessions. The political unrest goes back to the end of the Mobutu regime in the 1990s and the subsequent destabilisation of the country, despite the effects of the genocide in Rwanda (1994) and the invasion of troops from neighbouring Uganda and Rwanda at the end of the 199os (Clark

15 The names follow the famous example of Paris.

16 See http://hdr.undp.org/sites/default/files/hdr_2015_statistical_annex.pdf, accessed on 16 October 2018.

17 See http://www.worldbank.org/en/country/drc/overview\#1, accessed on 16 October 2018. 
2001). The desire for Congo's natural resources, together with ethnic rivalry and the related colonial heritage are the main causes of war. Since then, many countries and international organisations like the UN have been involved in the conflict, which has many regional or even local offshoots, especially in the eastern part of the country (Autesserre 2008). The continental impact is indicated by the designation 'Great War in Africa'. During the period of war in DRC other armed conflicts on the continent took place (Sudan, Uganda, and Angola), which were linked to the armed conflict in DRC (De Jong 2016, 12; Williams 2013). The election of Joseph Kabila in 2006 did not stop the violence. The large scale sexual abuse of women, one of the characteristics by which the wars in Congo became known in the North Atlantic world, continued in the period after his election, carried out not only by the military and civilians, but even by the peacekeeping forces. The practices of war seem to have created a culture of rape (De Jong 2016, 26-29) that continues to have an impact on the society and the children born from this abuse (Nyamujangwa and Nsimire Zihalirwa 2013). This is one of the indications that the ongoing unrest, war, and abuse of power have corrupted what is perceived as normal and culturally acceptable.

During the last two decades, the international relationships with North Atlantic countries have been dominated by the war and the peace processes. Four countries, Belgium the former coloniser, France, the UK, and the USA, have been the main participants. ${ }^{18}$ In 1996 France was on the side of Mobutu while the UK and USA chose the side of Uganda and Rwanda. The rivalry between the North Atlantic countries contributed to the impact of the war. When the Kabilas came to power, Laurent in 1997 and Joseph in 2001, things changed, and the USA and UK restored their bonds with Kinshasa. According to Gegout, however, the USA, UK, and France mainly continued to pursue their own geostrategic interests. In order to maintain their power and influence in francophone Africa, the French contributed significant monetary aid and military presence to DRC, but the latter was under the EU banner (Gegout 2009). From Gegout and other analyses of the conflict in DRC it becomes clear that Belgium's role was eclipsed by that of France and the EU, although its ongoing diplomatic efforts and substantial financial aid are recognized.

The cultural diversity of DRC is significant. There are 206 living indigenous and 5 non-indigenous languages spoken in the country, which has a population of nearly 80 million (2015). Some of these languages are mostly local, while others are spoken more widely. We make special mention of Lingala, a language

18 South Africa could also be mentioned here. See Kabemba 2006. 
used in Kinshasa and various regions and spoken by more than 2 million people. However, French is the official national language. ${ }^{19}$

Culturally, Kinshasa is a world apart. It is by far the largest city in the country and its central function on the levels of administration, economics, and cultural life has been undisputed since colonial times. In this city of approximately 10 million inhabitants, the mix of African and North Atlantic cultures has led to a creative and dynamic environment that is famous for its music, dance, and film productions (Pype 2016). With the capital of the neighbouring Republic of Congo, Brazzaville, only eight kilometres away on the other side of the mighty Congo River, it forms a unique urban area on the continent. In her study of the Christian film scene in Kinshasa, the anthropologist Katrien Pype gives a telling description of the urban culture, called 'La Kinoiserie' and 'KinKiesse'.

The ideal of a man with money and a girl with a beautiful figure is celebrated ... A Kinois is a talker. He likes to speak, often using deformed Lingala (kiKinois). He is a yankee, a gaillard, and believes he is above all other Congolese. He likes to dress well, despite his poverty... Even if he has nothing he is immaculately groomed. He likes beer and women, and dreams out loud of leaving for Europe... A Kinois will always find money, one way or another.

Needless to say, a conversion to Christianity in its Evangelical or Pentecostal forms, implies a severe criticism of this culture (Pype 2012, 29-32). Another important feature of this city is what Pype calls the "homogenizing work about ethnicity that is currently going on in Kinshasa" (Pype 2012, 237). Most ethnic groups lose their specific habits and practices, and instead a more urban culture is born. Pype shows that this city's culture is not particularly 'European' or 'Western' or related to one specific ethnicity, but is deeply rooted in older African traditions such as the belief in good and bad spirits. This phenomenon was evident in the focus group of students from Kinshasa. When they were asked to reflect on the influence of their African traditions on the model they built they said that they had very limited knowledge of their ethnic background. This is a remarkable difference compared to the students from Abidjan and Yaoundé.

19 See https://www.ethnologue.com/country/CD, accessed on 16 October 2018. 


\section{$3 \quad$ Education and laïcité in French-speaking Africa}

Before the disastrous scramble for Africa began, important intercultural encounters took place between the North Atlantic and African cultures. Western countries were already present in Africa long before the race to dominate the continent began. From the sixteenth century onwards, Portugal, France, Britain, and the Netherlands came to Sub-Saharan Africa and stayed there mainly for trade purposes although military interests also played a role. Apart from the massive slave transportations, contact with the local peoples was limited. However, the changing understanding of the function and the impact of this presence during the second half of the nineteenth century made the presence of the European countries on the continent far more intense (Newbury and Kanya-Forstner 1969). The development of these European political ideas was preceded by a renewed interest in Africa from the USA and the UK, as expressed in the founding of communities or colonies and then finally states for Afro-Americans or Afro-English people in what became Liberia and Sierra Leone (Ojo and Agbude 2012).

Furthermore, the increased missionary activities, especially by mission societies and orders, were partly orientated towards Africa but must not be equated with colonisation (Sanneh 2009, 142-155) despite there being certain links between mission and colonisation as we will argue below.

\subsection{Christianity in Africa}

For a proper understanding of our subject, we must elaborate on the relation between the African continent and Christianity. For African Christians, North Atlantic missionary history should not be isolated from the older history of Christianity on the African continent.

Both in the Old and New Testament, one encounters exchanges with Africa, famously in the presence of the Queen of Sheba in the Old Testament and the Ethiopian Eunuch in the New Testament. ${ }^{20}$ Christian communities were established in North Africa from the first century onward and contemporary churches in Egypt and Ethiopia date their origins back to the first centuries of the Christian era (Sundkler and Steed 2000, 7 ff; Oden 2007, 18-26).

Though modern African Christianity's origins, specifically in the countries of this study, are mainly North Atlantic, the symbolic value of these earlier influences is significant. African Christian communities and theologians often refer back to these early African origins in order to point out that Christianity is not simply a white man's, or Western, religion. In many Independent African 
Churches the Ethiopian church is held in high esteem and has a crucial symbolic value, even where direct historic links might be non-existent (Hastings 1994, 478-487).

Recent studies have also pointed out that the relationship between modern missions and colonialism was ambivalent. Most missionaries in the modern era would to an important degree have accepted the notion that their role was not only to proclaim the Gospel, but also to 'civilise' the heathen. This was an automatic consequence of the idea that European and North American civilisation was the fruit of Christian influence. This has, of course, led to the accusation that Christian mission in Africa was an instrument of Western colonialism (f. ex. Mugambi 1992). This does not, however, mean that missionaries saw themselves as agents of colonial powers. Missions had their own agenda for which they considered themselves accountable to God and were consequently willing to criticize colonial administrations if they believed they were abusing their power. Yet, particularly in the case of missionaries who did not originate from the colonial nations themselves (such as in the case of Swedish or North American mission agencies working in French-speaking colonies), their political influence was limited given that their residence permit could be withdrawn by the colonial administration. Their educational policies could also have different interests. In a number of cases, mission agencies wanted to begin primary schools in local African languages, but the French colonial administration only permitted schools that would use the French language and would thus contribute to the civilising project of the French government (Janzon 2010).

More importantly, it is increasingly clear that the indigenous collaborators played a crucial role in the spread of Christianity in Africa. These local catechists and evangelists were the primary mediators between the expatriate missionaries and the local population. Nevertheless, they were not simply the mouthpiece of the missionaries but understood its content and importance in their own manner, in a way that made sense to them in their own cultural vocabulary and social context, and they communicated it accordingly (Sanneh 1983).

The ownership, or at least co-ownership, of Christianity by Africans themselves even before political independence from the colonial powers is probably revealed most clearly by the many independent Christian African movements that rose in the margins of the church. In their earlier stages, these movements were often started by collaborators of Western missions turned African Christian prophets. They intended to present a form of Christianity that was both free from Western institutional structures and from Western cultural dominance. For the countries under our consideration, we can point as 
an example to the prophet William Wade Harris in West Africa (c. 1860-1929) (Hastings 1994, 443ff; 505ff) and Simon Kimbangu in the Congo region (18871951) (Hastings 1994, 508ff), who both attracted millions of followers. In the modern urban environments in which the students and academics of this study function, recent charismatic movements are even more important than these older African Independent Churches. These churches and para-church ministries developed out of revival movements in the final decades of the twentieth century, and now represent some of the most numerous groups in African Christianity. Though these groups are sometimes seen as an expression of North American influence, it would be more appropriate to see them as a global phenomenon that strongly resonates with an African cultural and religious heritage (Omenyo 2002).

In many places in Africa, an encounter with missionaries was the first meeting with people and cultures from the North Atlantic. When it comes to education, these encounters have in many cases been at least as decisive as the coming of modern colonialism. An example is the special encounter between the team of the Jamaican Baptist Missionary Society and the inhabitants of the coastal area of what is called now Cameroon in the early forties of the nineteenth century. These first missionaries were mainly liberated slaves who wanted to share the gospel with the people of the countries they hailed from. The Jamaican mission post was handed over to the London Baptist Mission in the fifties but some of the Jamaican missionaries continued to work there. A translation of the gospel of Matthew had already appeared in 1848 and was followed by the complete New Testament in 1860. Of course, both required a form of school education in order to read it (Messina and Van Slageren 2005, 27-31). All Christian missions in Africa were engaged in education. According to Gallego and Woodberry "over 9o\% of Western education in sub-Saharan Africa during the colonial period was provided by missionaries" (2010, 298299). These authors underline the specifically protestant emphasis on the importance of Bible translation and subsequent education in the local languages. Translation and the use of the vernacular form a crucial element of the work of the historian Lamin Sanneh (cf. Sanneh 2009). He even argues that the use of the vernacular by the missionaries encouraged opposition to colonial rule. He also points to the discouragement of the use of the vernacular by the authorities in francophone countries because of the possible threat to the state (Sanneh 1992, 96).

\subsection{African Traditional Education and Worldview}

Although the education offered by the missionaries is an important starting point for understanding the intercultural exchange between Africans and 
people from the North Atlantic world, educational processes were already a common phenomenon within indigenous communities since time immemorial. Although little is known about education in the era before the Westerners came, there is evidence of very old forms of science and of what is called African Indigenous Knowledge. This knowledge and its transmission cannot be understood apart from the concrete societies in which it arose, and it must therefore not easily be universalised as 'African', although "commonalities between these bodies of knowledge" must not be excluded (Emeagwali and Shiza 2016, 9). More recent studies of personal formation in ethnic groups give at least an idea of some important principles of traditional education. Based on the principles of preparationism (preparation for the roles in society, i.e. initiation), functionalism, communalism, perennialism (maintaining status quo, preserving cultural heritage), and holisticism (very few specialisms), girls and boys were educated in a mostly informal setting (Adeyemi and Adeyinka 2002).

Some of these principles can be recognized in the discourses of the students and academics that we studied. For example, during the research sessions with the students from Yaoundé the participants presented a typical 'African' approach in contrast to the so-called 'Western' or 'European' understandings (see Chapters 4 and 5). The essence of the African perspective as worded by these participants is related to the worldview expressed in the traditional education described above. The rich heritage of African philosophy and theology presents, and elaborates on, this perspective. Therefore, we briefly mention the work of some African philosophers and theologians to offer a broader horizon for the interpretation of the discourses.

Fifty years ago, Mbiti gave the following explanation in his classic study, $A f$ rican Religions and Philosophy:

It emerges clearly that for African peoples, this is a religious universe. Nature in the broadest sense of the word is not an empty impersonal object or phenomenon: it is filled with religious significance... The invisible world is symbolized or manifested by these visible and concrete objects of nature... The physical and the spiritual are but two dimensions of one and the same universe... To African peoples this religious universe is not an academic proposition: it is an empirical experience, which reaches its height in acts of worship.

мвіті 1969, 56-57

This perspective implies a normative and ethical framework (Magesa 1997, 71-76) and has been incorporated into Christian theology in various ways 
by many African theologians. Here we give some examples of theological expressions from the three major Christian traditions - Roman Catholic, Protestant (Reformed), and Pentecostal - that explain the relevance of this perspective for African Christianity.

Jean-Marc Éla (1936-2008), a Roman Catholic priest from Cameroon, testified of the great divide between what he called the Christianity of the missionaries and daily life in Africa. In his powerful book, Ma foi d'Africain, he advocates a Christian church and theology that is open to the African way of living and understanding life in order to free the gospel from a Christianity that has become too middle class (Éla 2001, 52). He describes this African way of living as a symbolic order: "The symbolic order in Africa concerns the whole drama of existence that expresses the relationship between human beings and the invisible. Any religion is itself a total language, a means of expression allowing people to grasp fully their unity with the entire world, and to communicate with it" (Éla 2001, 35). And therefore, he argues that sickness, for example,

is not felt as a phenomenon that comes to strike a particular individual, but rather as a disturbance of social relationships. [...] It makes sense that the techniques of healing cannot be separated from the symbolic universe from which they emerge. [...] Thus the African universe of sickness is inseparable from the universe of spirits [...].

ÉLA 2001, 50-51

The second example is from the work of the Ghanaian Reformed theologian, Kwame Bediako (1945-2008). Bediako has contributed to a broad appreciation of what H.W. Turner called the 'Primal World-View' in Christian theology, stressing the continuities between the African traditional religions and the Christian faith (Cf. Chapter 6). Drawing on Turner, Bediako brings Western theology's typical emphasis on God's transcendence into dialogue with the primal world-view, a "unified cosmic system, essentially spiritual, in which the 'physical' acts as sacrament for 'spiritual' power" (Bediako 1995, 101).

Like Éla, Cephas Omenyo, a Ghanaian Reformed theologian with special interest in Pentecostal theology, underlines the differences between the theological presuppositions of the missionaries from Europe and the US and traditional African understandings. He further points to the decisive importance of the socalled African Initiated Churches, a distinctively African response to the Gospel (Omenyo 2002). He argues that although the Charismatic churches make similar positive connections with the primal worldview, they are also critical towards African Initiated Churches. The latter include all kinds of traditional 
rituals, etc., which Charismatics usually label 'demonic.' ${ }^{21}$ Ogbu Kalu's impressive African Pentecostalism: An Introduction (2008) offers a broader picture of the confluence of biblical, African, and missionary theology in African Pentecostalism. His analysis of the 'Prosperity Gospel' gives a nice example of how these threads are woven together, with a central role for wholeness:

Abundant life among the Akan resonates with the Hebrew concept of shalom, denoting total wholeness that is physical, psychological, spiritual and social. For the African, it describes peace with God, the gods, ancestors, fellow human beings... and the natural world.

KALU 2008, 261

These examples show that the need to relate the 'African approach' to the Christian faith of Africans (referred to by the students from Yaoundé, as well as the academics from Abidjan and Kinshasa), is part of the discourse of theological expressions and analysis from different denominational backgrounds. We will return to this specific African understanding in relation to the intercultural debate on science and faith in the last two chapters of this book.

In order to examine formal education in the colonial and postcolonial eras, we focus on the use of laïcité in francophone Africa. The research offers the opportunity to test the hypothesis that in a society in which laïcité dominates state education, schooling affects the individual's understanding of science and religion. The difference between Abidjan and Yaoundé, where educational systems are modelled according to the French ideas on laïcité, and Kinshasa, where this is not the case, is therefore important. Laïcité is directly related to developments in the French Republic in the nineteenth century and its efforts to separate state and church. When we examine the developments of the understanding of this concept in France's colonies, it helps us to see how education and science were introduced with a clear bias that created a problematic relation between traditional beliefs and Christian faith. Although the reception of laïcité in Africa was far more confused and ambiguous, in general, the normative element concerning the relation between education/science and Christian faith/religion survived.

21 See the comment of Martha during the second research session of the academics from Yaoundé, Chapter 4 and Chapter 5 . 
Below we will explain the most essential elements of the understanding of laïcité in France, and during the intercultural exchange in the French colonies as well as in the independent states of Ivory Coast and Cameroon. Laïcité did not have a similar impact in Congo because the Belgians maintained a more traditional outlook on education as we will elaborate in the last part of this section.

\subsection{Laïcité in France}

The concept of laïcité is closely related to modern French cultural identity as developed during the nineteenth century and is firmly rooted in revolutionary ideas and values. It expresses the notion of separation between state and religion(s) in France (Baubérot 2002). When laïcité became a regulative principle for state education in the second half of the nineteenth century it caused conflict, especially with the Roman Catholic Church (Lalouette 2005). Jules Ferry, minister of education and later prime minister, is the personification of the laïcité policy (Chadwick 1997). Some scientific developments were perceived as contradicting the Christian faith and the church opposed these developments, as well as the strict separation of science and faith. For example, the rise of prehistory and archaeology challenged the anti-modern stance of the Roman Catholic Church (Defrance-Jublot 2005).

Chadwick points to two important changes that led to a new situation after World War Two in which a different policy of laïcité was born. First, after the war the state's leading position in the field of education (both in quantity and quality) seemed to be completely accepted. Additionally, the Roman Catholic Church saw the positive side of laïcité, in that it would guarantee its independent position and freedom of expression. This new situation made a different policy of laïcité possible, which was then given concrete form in two laws concerning the co-payment of private education by the state and the implied further control and regulation of private education by the state. Chadwick writes: "Where laïcité in the 1880 s meant social and national unity, laïcité in the Fifth Republic France has been increasingly defined in terms of flexibility, freedom of choice, and the recognition of difference (laïcité - liberté)" (1997, 53). Nevertheless, the disputes about the headscarf (foulard) in school from the late $1980 \mathrm{~s}$ until at least 2004, when parliament passed a new bill, brought laïcité back to the forefront of the political debate (Chadwick 1997, 55; Lettinga 2011, 121-153). Chadwick perceives these recent developments as a regression of the interpretation of laïcité as it shows that a modus vivendi with Islam has not (yet) been reached in French society $\left(1997,5^{1-58}\right)$. However, these developments confirm the French understanding of laïcité as the strict separation of religion and state. 


\subsection{Laïcité in France's African Colonies}

Starting with the conquest of Algiers in 1830, France gained a large territory in North- Western Africa, and after 1885 territories in sub-Saharan Africa were conquered systematically. French Africa was therefore a vast area that could not be administrated in the same way as France. Madeira asserts that initially the French colonial style, which is often perceived as an expression of assimilation politics, was not so different from the so-called laissez-faire politics of the British. In both cases, 'indirect rule' was a dominant practice $(2005,36)$. During the nineteenth century, education in the African territories under French governance was left to missionaries and decisions were made locally. Nevertheless, this education policy changed at the beginning of the twentieth century. From then on, missionary assistance was turned down and the African school system was to be conformed to the leading ideas of Jules Ferry (Madeira 2005, 43-44). However, this does not rule out Daughton's observation that at least until the First World War, "the so-called republican civilizing mission in the French empire was regularly carried out by the republic's sworn 'enemies' Catholic religious workers" - because "few politicians or colonial lobbyists were willing to pay (or ask taxpayers to pay) for the programs they promised" $\left(2006,5^{-6}\right)$. The registered mission schools were controlled by the colonial power. In the colonies of Roman Catholic countries, there was less freedom for Protestant missionaries and therefore the relation between Roman Catholic mission school and state was close. This was certainly the case in the Belgian Congo and officially only during the nineteenth century in the French territories. In the German colony Kamerun there was open competition, and Roman Catholics and Protestants from various backgrounds offered education as part of their mission work (Gallego and Woodberry 2010, 298-301). The situation was therefore quite different in Cameroon, because under German rule education had been mainly in local languages (Fouda 2005, 83-98). However, after World War I, the government of the biggest part of the country came into the hands of France. However, the diverse cultural influences on Cameroon's educational system did not prevent the French from implementing French as the official schooling language as stated in the decree of the 1st of October, 1920: 'L'enseignement de toute autre langue est interdit' (Ngonga 2010, 21-22). Free schools were therefore only permitted if they offered education in French $(\mathrm{Du}-$ praz 2013, 12). Compared to the British colonies where education was offered by missionary schools in local languages, the French system generally meant that fewer children went to school. The policy of state schools and education in French therefore made schooling elitist (Frankema 2012, 4).

The so-called 'civilizing mission', in which French language played a central role and which meant that Paris had more control over the education in the 
colonies, provoked inequalities (Chafer 2001, 196). From the beginning of the twentieth century it was believed that assimilation was not an appropriate ideal; Africans had to evolve within their own cultures. Madeira argues that although education was adapted to the (French perspective on the) demands of the African situation, culturally it was not oriented towards indigenous life $(2005,43-45) .{ }^{22}$ Alice Conklin explains how the 'adapted education' was coloured by patriarchal perceptions of Africans as big children or women. Conklin's research leads to the conclusion that the aim of education in the two spheres was completely distinct. Whereas French children were prepared for "citoyenneté," the education of the Africans was aimed at the formation of "hommes utiles" (Conklin 2002, 163-166; Dupraz 2013, 2). French education in the African colonies was therefore principally different from that in France, including the practices regarding laïcité (Quist 2001, 301-302).

This situation changed because of the consequences of the Second World War. Especially under the influence of the Brazzaville Conference of 1944, the schools in the African colonies received more money from Paris, and secondary education in particular was reinforced (Dupraz 2013, 13-15). The more flexible understanding of laïcité in France after World War II came closer to the practices in the colony where the separation between state education and church had never been so strict, especially now access to education in Africa was increased. In 1957 a university was founded in Dakar, and the famous I.F.A.N (Institut français d' Afrique noire) was affiliated to the university (Toure and Cisse 2008, 64-68). This university was not imposed by the French but was the fruit of indirect influence and the wish to make the education of the colony equal to that in the métropole, especially from the African members of Parliament in Paris. Education in the French colony was now (more or less) in line with the situation in France, but this also made the French colonies in Africa more dependent on France's education system. Therefore, in the context of the coming independence these reforms became increasingly ambivalent (Gamble 2010, 162).

\subsection{Laïcité in Postcolonial Ivory Coast and Cameroon}

The aim of the African members of the French Parliament to make education in the African colonial territories equal to that in France became the leading idea in Ivory Coast's education policy during the first decades of independence (Quist 2001, 302). The idea of laïcité survived independence as well and Ivory Coast became a secular state (Miran-Guyon 2013, 317). Here the Roman Catholic mission schools remained independent but counted on the support of 
president Houphouët-Boigny and were able to build a large network of private schools throughout the country. This support allowed many French missionaries to work as teachers in Ivory Coast and reinforced France's cultural influence. Until the end of the eighties, the specific policy of Ivory Coast to integrate Catholic education into the state program, while respecting its confessional character, was the intention of both the state and the church's leadership. Financial problems, and political developments towards democratization, forced Catholic education to search for an alternative route for finances.

The consequences of the new situation were dramatic, especially in the rural areas where most of the Roman Catholic schools had to close down (Lanoue 2003). In this case it was democratization and the loss of its privileged position, rather than a strict application of laïcité, that led to the diminish of Roman Catholic education. Nevertheless, laïcité was an important argument used by the Muslim majority to oppose the partial support of Roman Catholic education by the Ivorian state. Houphouët-Boigny had also favoured certain Muslim organizations (with money for pilgrimages for instance) in order to balance the political situation, but had not done the same in the field of education. The smaller favours for the Muslims kept them quiet for quite a long period of time (Savadogo 2013), but this changed during the nineties and onwards, when they claimed equal rights and finances for Muslim education (Miran-Guyon 2013, 321-326). By then, however, the 'golden age' of financed confessional education had gone. The policy of laïité during the long governance of HouphouëtBoigny had covered the practice of giving privileges towards the education of the president's peer group and had safeguarded the continuity of French cultural influence. The network of cultural and educational relations France constructed with its former colonies in Africa confirms that this policy was actively supported by Paris (Manière 2010). Although Houphouët-Boigny's education policy appears to be a form of clientelism, in practice it was not very different from the interpretation of laïcité under colonial rule. In the education policy of laicité during colonization, Roman Catholic education was favoured, often indirectly and against the explicit political preference of Paris, to safeguard education in French language and culture. Laïcité had therefore been introduced and made fashionable by politico-cultural and financial interests. When this practice was continued after independence, laïcité was no longer an instrument to safeguard the separation of state and religion but was used as a justification to manage the (politico-cultural) interests of those in power. In this conception, however, there is also place for what could be called the religious 'neutrality' of the state, as evident in its attempts to balance favours to different religious groups.

After independence, Cameroon's situation continued to be somewhat different as education became bilingual (Ngonga 2010). The difference between 
public and private education in the francophone and anglophone regions was annihilated. In both parts of the country, $80 \%$ of the pupils go to public schools (Ngonga 2010, 84-91). Charles Manga Fombad argues that the 1990s marks a new period in the postcolonial era, because Cameroon moved towards a more democratic system, as was also the case in Ivory Coast $\left(2015,25^{-28}\right)$. The first years of this period were characterized by political and social unrest, in which language barriers, and especially ethnic divisions, revealed new dimensions of the political landscape. The Roman Catholic sector of society, nearly $40 \%$ of the population, represented various political stances. The actual laws on the neutrality of the state formulated during the nineties were mostly applied in a more pragmatic than a principled way (Fombad 2015, 35). The economic crises caused the impoverished state to search for finances for education, health care, etc., and churches and religious organizations were willing to contribute in these areas. However, the position of the churches, especially the Roman Catholic Church, became more antagonistic toward Biya's government. Although he was first hailed as a defender of Christian values, the divergent perspectives on the Catholic schools created a tense situation between state and church. The Roman Catholic Church maintained this critical attitude during the nineties and onwards, addressing the abuse of ethnic tensions for political reasons, corruption and the like (Konings 2007).

We conclude that the colonial use of laïité was strengthened in postcolonial situations. Politico-cultural interests, often regulated by a substantial financial component, determine the understanding of laïcité (Fouda 2012, 7180). In particular, the 'pragmatic' use of laïité in the context of financial crisis shows the importance of two elements: the growing importance of ethnic and cultural belonging and the rise of what is called the NGO-isation of the field of schooling as a consequence of the (partial) liberalization of the education market (Dilger and Schulz 2013, 370). Nevertheless, the use of laïcité for principled reasons defending the opposition between (higher) education or science and religion still plays a major role after independence. The biased understanding of this relation that is presented by laïcité can be easily found among scientists. During the preparation of th field research, when we asked Christian university professors how they understood the science and religion question, some defended a clear separation between education or science and their faith. This is not, however, a common stance among the Christian academics we talked with during the orientation phase of our research, as is confirmed by the discourses we present in the next chapters. Nevertheless, professors who work at a state university in Cameroon or Ivory Coast have to deal with certain limitations when it comes to expressing their faith at university.

Finally, intimately related to the idea of laicité is the understanding of science as the highest and ideal form of knowledge (because it is neutral and 
indisputable) that is widely accepted in the North Atlantic world. Taede Smedes uses the term 'cultural scientism' to indicate the nearly absolute status of scientific knowledge in the Western worldview (Smedes 2008, 241-242). This understanding of science was never expressed by the participants of our research. On the contrary, in several group sessions they mentioned the ambiguous appreciation of science in their societies, Take medical knowledge for example, although people visit doctors and undergo medical treatments, they also look for treatment through traditional healers and priests or pastors. As is discussed in Chapter 5 , they are not convinced that medicine alone will cure.

\subsection{Education Outside the Influence of laïcité: The Democratic Republic of Congo}

As a former Belgian colony, the DRC has a particular status in francophone Africa. Barbara Yates mentions the 'Big Three' that dominated Belgian colonialism: the Roman Catholic Church, the colonial administration, and the large companies. Schooling was attributed to the first, and at independence in 1960 , $77 \%$ of the pupils attended Roman Catholic, and $19 \%$ Protestant, institutions. Thus, education was to a large extent in the hands of missionaries, and they handed over their worldviews and ideas (Yates 1982). This monopoly of the churches was briefly interrupted by Mobutu's regime, which nationalized the mission schools in 1974. However, without the churches Mobutu was not able to avoid the collapse of the system, and in 1977 the regime reconvened with the churches and the Muslim organizations to establish national education in five networks: the 'non- conventionized' network directed by the state, and the Roman Catholic, the Protestant, the Kimbanguist (an indigenous church), and the Muslim directed by the faith communities. This system still exists, and most children attend religious schools, with $50 \%$ of pupils in Roman Catholic schools. During the Mobutu government, the state continued to retreat from education and dropped the salaries of the professors. By the end of the twentieth century, the system could be called 'privatized' (Titeca and De Herdt 2011, 223; Titeca et al. 2013, 120-122). Schooling increased after 2002 under Joseph Kabila, but in 2012 the website of Global partnership for education mentions that it is "one of the countries with the largest number of out-of-school children." ${ }^{23}$ School fees are one of the major barriers to education, and actually "the state has lost its position as final regulatory authority; instead, this role is negotiated between various actors rather than being claimed by a supreme authority (the state)" (Titeca and De Herdt 2011, 230). The D RC seems to suffer

23 See http://www.globalpartnership.org/country/democratic-republic-of-congo, accessed on 30 October 2018. 
from an even stronger NGO-isation of education than Cameroon, because nobody has the final power to decide. This short overview of education in the DRC makes it clear that the state has never been such a dominant player in the field of education that it could impose secular education (laïcité) on a large scale. In view of the country's situation and the government's decreasing involvement, it is not likely that this will be the case in the near future (Titeca and De Herdt 2011). If children are willing and able to go to school, most will receive education at religious schools. Chapter 5 will reveal the impact of this context on the researched discourses about science and faith from Kinshasa.

\section{Universities}

The universities in francophone Africa are nearly all postcolonial institutions that have been founded with the above-mentioned desire to raise the level of education in Africa to the level of that in the métropole. We have already mentioned some famous state universities in Ivory Coast and Cameroon, and we could add the Université de Kinshasa as an example in the DrC. Although these universities have interesting local academic programs, as well as exchanges with other universities in the world, they struggle with some major problems. Niang points out that political instability and wars in the regions do not create an adequate climate for scientific research (2005). Also, failing national governments and university authorities that neglect the importance of scientific development and research appear to be an obstacle. Even academics of higher rank often see research as "a simple occasional instrument of self-promotion" rather than as a vocation or a domain of scientific self-actualisation, which creates "une culture de non-recherche" (Niang 2005, 81-82). The author proposes improvements to the academic system, for example better salaries for the professors and real freedom of speech on all levels, as well as a democratic and transparent handling of the funding destined for research (Niang 2005, 93-94). Niang's analysis corresponds to what we learned from our research. The unrest at the Cocody campuses in Abidjan in 2015 was also related to a lack of transparency and the salaries of the professors. Furthermore, in the sessions with students in Kinshasa and Yaoundé it appeared that a course of study at university, including a Master of Research degree, is mainly perceived as being favourable for your career rather than motivated by a desire for knowledge or by science as such. ${ }^{24}$ This reveals that not only the

24 See the second research session with students in Kinshasa and third session with students from Yaoundé. 
staff but also the students are prejudiced by the failures of the institutions, and explains some of the motivations behind the long story of student opposition and revolt told by Pascal Bianchini (2016). The history of the student movement in francophone Africa is therefore highly political and the situation in Cameroon in the 1990 s is a good example of this. The struggle for participation and transparency, and against the authoritarian behaviour of the institution's leadership. is linked to the political fight outside. These characteristics of the university leadership also make it understandable that they use laïcité for their own benefit. In some of our interviews with professors and students during our first orientation trip in January 2015, they talked about the selective use of laïcité by the leadership of the university. This is completely in line with its application on the national level, in both colonial and postcolonial times.

\section{$6 \quad$ Conclusion}

This overview of the intercultural dynamics in Cameroon, the DRC, and Ivory Coast indicates that the cultural diversity within these countries, and the role of French (and partly English) to make national communication and national identity possible, stimulate an ongoing intercultural exchange. However, the political manipulations of this diversity, as performed by the colonial and postcolonial administrations, provoke unrest, conflicts, and even wars. Formal education is one of the favourite domains for culture politics. In this domain the contribution from outside, especially from the North Atlantic world, has always been very important. Education has been connected to religion, and especially the churches, from the arrival of the first missionaries to the strong NGO-isation of today. However, with secular state education the French introduced another tradition. Laïcité has been a useful instrument for culture politics and the state universities are still places where the idea of laïcité has a certain impact. In these postcolonial institutions the political use of laïcité has survived, but it is also understood as a principle for separating science and scientific education from religious beliefs. 